\title{
A Brief Analysis on Elite Democracy in
}

\section{Authoritarianism Countries}

\author{
Jia Hong \\ School of International and Public Affairs, Shanghai Jiao Tong University, Shanghai 200240, China \\ Tel: 86-21-54748882 E-mail:jolean_1984@hotmail.com
}

\begin{abstract}
This paper, commencing with the revision of classical concepts on democracy, puts forward that democracy is not only the aim but also a kind of means and method, based on which the paper further analyzes the shaping of democracy, and points out that elite democracy is an inevitable trend and that the role and function that elite democracy plays in the process of democratization is the exhibition of democratization strategy piloted by elites. In the last part of this paper, the author presents the relationship between elite democracy and authoritarianism and points out the development direction for elite democracy in authoritarianism countries.
\end{abstract}

Keywords: Elite, Democracy, Shaping, Elite democracy, Authoritarianism

\section{The essentials of democracy}

\subsection{The revision of classical democracy}

Classical democratic theory essentially means "people's politics" or "the majority's politics", nevertheless, the facts apparently make clear that in reality a democracy mode that complies with classical democratic theory does not exist at all. Confronted with the contradiction between classical democratic theory and the reality of western democracy, Webber and Schumpeter chose to adopt experiences and demonstration. They are of the view that since most people could quite uniformly distinguish democratic counties from totalitarian countries, there must be great substantial differences between the two kinds of countries. Therefore, a democratic theory that starts from experience and can distinguish democratic system from autocratic system is needed, whereupon, the elite democratic theory, a revision of classical democracy, emerged as the condition required.

The main views of elite democratic theory are summed up as follows: (1) democracy is governed by elites or politicians; (2) the society is divided into minority with power and t majority without power; (3) democratic policy means a competition process among many elites, of which party competition is a typical one; (4) in democratic society, citizens will termly select their decision-makers though voting; they may influence the decision-making process in view of group interests; (5) elite group is an open system, where everyone is equally entitled to enter into; (6) the influence of elites on the public is far higher than that the public on the elites.

\subsection{Democracy in elite democratic theory}

Theorists of different times had made discussions on elite democracy. Webber, on the basis of democratic mechanism, put forward an elite ruling mode "bureaucratic democratic system". The gist of this kind of mode is that elite ruling is conducted with the regularly participation of the public and the political actions of bureaucratic government and elites are restricted by general election system and powerful parliaments selected by the public.

The elite democracy views of Schumpeter realize the combination of democratic theory with elite theory, eliminate the inherent values of democracy, and put the tool value of democracy at the first place among the values of democracy. He is of the opinion that "Democratic method is an arrangement of system aiming to attain the power to make political decisions. In this kind of arrangement, some one attains the power for decision-making through running for votes from the people."

In A Preface to Democratic Theory, Dahl first endowed elite democracy with an independent concept, "pluralist regime". He thinks, "A democratic society can be defined as a social system, which not only has democratic political system but also has many other sub-systems that directly or indirectly function as democratic political process." In this connection, democracy can be defined as "the ruling of pluralist minority".

\subsection{The necessity of elite ruling}

In the views of elite theorists, elites' ruling and governing society is an inevitable and unchangeable rule and no society 
including democratic society can avoid this rule. The inevitability of elites lies in that in all organizations there exist the powerful drive for the emergence of oligarch, whose interests are different from and exceed those of the common members of their organizations, the ruling of minority political elites on the public is realized through organizations, and the former is an organized group, while the people in majority are just unorganized public.

\section{The shaping of elites and democratization}

\subsection{The functions of elites in the process of democratization}

Now that the elite ruling is inevitable in democratic society, the problem is that why they can play the key role in democratic society.

First of all, the public is a kind of indifferent and non-rational political power.

Kornhauser believes that modern society is an atomic society, where people have always been lacking interests in politics. "The public do not lead, but follow. They just respond to the attitudes, suggestions and actions of the elites". This kind of indifference shows people's dissatisfaction of the system because the politics is maneuvered and mobilized by state elites and the public is easy to be mobilized by elites

Secondly, elites are a kind of ardent and rational political power.

Elites are a group of people who have divine intelligence and social and economic statuses, and are members with powerful force inside social groups. They live and work in intermediate level in cities, are the elite force that can advance the development of various social industries, have active spirit, are willing to accept new matters and theories, are concerned about hot social issues, devote themselves into social commonweal businesses, and positively promote the advancement and development of society.

Many scholars take political elites as the most importance factor in the process of democratization. The feature of democratization since 1970s is that the transformation of democracy comes from the upper level, which is dominated by elites. Huntington has explained in his book The Third Wave of Democratization that the most important factor in the time of the third wave of democratization is the believes and actins of elites.

\subsection{Examples of elites' consolidating democracy}

Democratic regime is just a threshold, while the most important issue is to consolidate democracy. Some scholars are of the view that from the perspective of elitism, the consolidation of a democratic regime, besides that the public widely participate in election and other political activities, requires that elites search common grounds and be consistent with each other and solidified, which will exert great influence on the stability of democratic politics. Elites and Democratic Consolidation in Latin America and Southern Europe conducts detailed researches on the relationship between elite change and democratic consolidation of 13 countries in Latin America and Southern Europe (please refer to the following table).

Seeing from history, elites in most of countries lacked common grounds and solidarity, which resulted in the instability of regimes, which means that the regime is a faked democracy or democracy not consolidated. If elites wanted to search for common grounds and be solidified, the tendency and structure of elites shall undergo a substantial change. The consolidation of democracy cannot be realized through one or two day's effect. Elites play important role in the consolidation of democracy. For example, in the achievements of Latin America, leaders had played decisive roles. Through the analysis of the aforementioned types, we can come to this conclusion: "elites are the switchmen of history"; the common grounds and solidarity of elites is a prerequisite for the consolidation of democratic regime.

\section{The democratic strategies of elites}

\subsection{The demands of elites towards the public}

In democratic society, the ruled class can always force the decision-makers to consider the interests of the majority when making decisions. The public also play important roles and sufficient attention shall be paid to them.

Firstly, elites need the supports of the public. Schumpeter sees that decision-making needs to gain supports from the voters all the more. In order to gain this kind of supports, the thoughts of elites must be in consistent with the interests and political tendency of the public. The assumption of elites needs to be consistent with the interests and tendency of the public, while this kind of relevancy restricts the actions of elites. The interests and tendency of the public becomes a parameter, in which elites can safely and effectively bring into play their functions.

Secondly, elites need the surveillance by the public. Even in democratic society, it is possible for elites to abuse their power. Therefore, the key point is to effectively control the elites and establish a "responsibility system" for elites towards the public. Even though in democratic regime elites still control the power and the public enjoy small quality of power, the small quality of power can control elites and enables elites to shoulder their responsibilities.

Thirdly, elites need the actions of the public. Some elitism theorists have pointed out that public actions are actually beneficial for the maintenance of democracy. Labor unions, farmer organizations, church groups, and various associations have played important roles in combating authoritarianism government and establishing democratic regime. Democratic 
politics is a system where the rulers and the ruled interact and are mutually responsible for each other.

\subsection{The guidance of elites on the public}

First of all, the voice power is transferred to the public. The emergence of internet in $20^{\text {th }}$ century makes "internet democracy" the best chance and bridge. The voice power extended from elite level to civilian level at a speed not controlled by people's will. The newly emerged Blog is an apparent exhibition of the voice power of the civilians. The rapid extension of the voice power to civilian level enables the whole society to be more sensitive about unexpected accidents. The interest tendency feature reflected by voice power undergoes delicate change: once it is found that the interests of civilian level or weak groups are severely infringed and cannot be solved in a justified way, a strong public voice will be spontaneously formed to fight for the interests and condemn the responsible parties.

Secondly, citizen societies are gradually formed. Many western scholars believe that the existence of citizen societies is a prerequisite for the realization of political democracy. American politician Barber believes that in the USA, there are two kinds of democracy: one is state democracy, represented by the conflicts between the two parties, presidential elections, and the policies of federal organs; the other is local democracy, represented by neighborhood organizations, parentalteacher association, and community action groups, and etc, whose range is generally limited to a city, a town or a county in the countryside and where people are easy to from a small group to resolve divarications and find out methods to cope with common problems. In most state affairs, these common citizens are just lookers rather than actors. On the contrary, in local or community affairs, they become active thinkers and actors. "Politics" there is no longer "theirs" but "ours".

\subsection{The transition between elites and the public}

In any society, elites are not changeless but rather flowing. Education shall be adopted to impel the public to transform into elites and to push the circular development of the society. Pareto stresses, "Through a continuous process, new elites come into being in the lower level of the society. They then ascend to higher levels and reach their prime there. Afterwards, they incline towards degeneration. Finally, they are either annihilated or vanish. The corresponding result of this elite circular process is the gradual change and improvement of social status."

\section{Inspiration for China}

\subsection{The transition from totalitarianism to authoritarianism}

Totalitarianism means that the control of government on society is all-pervasive. Authoritarianism means that government has comparatively large authority, but is usually limited to political aspects, and does not intervene much in social and cultural aspects. The differences between these two systems are obvious. Authoritarianism is a political form lying between totalitarianism and democratism.

China, at this stage, is in transitional stage from totalitarianism to authoritarianism. For one hand, Communist Party still has absolute power in politics and the power of Communist Party on culture, education and propaganda is still of totalitarianism nature. However, for another hand, the social culture and people's life in China are almost as free as those in the west are. We can make use of authoritarianism tools, keeping their essence and discarding their defects, to promote and accelerate the democratization process of China and use the authority power of government to promote economic development of China and maintain political order in reforms, which is not in contradiction with our effort towards democratization. Because authoritarianism is evolving too, what we emphasize is the transition towards democratic authority and the optimization of the application of authority under the frame of democratization.

\subsection{From authoritarianism to elite democracy}

Authoritarianism is a transitional status of developing countries in their process of modernization. It is a system of the nature "both sides can be shaped" and is a transitional system lying between totalitarianism autarchy and modern democracy. It may march toward, develop and change into modern democracy and may also fall back and degenerate to totalitarianism autarchy. Democratization is a necessary trend of the development of human society. The roads that different countries take to develop towards and realize this ultimate aim are somewhat different. From the perspective of the democratization process of East Asia, generally, it is a triple jump from traditional politics to authoritarianism and then to modern democracy. It is a gradual process where economy modernizes first and politics modernizes subsequently and on the basis of economic development, political democracy is promoted. Historical experience has proved that to hastily discard authority will result in modernization losing its way. Without authority, society will be like scattered sands and it is hard for society to act in phase and in conformity. However, in different development stages of different societies or of a society, the connotation and rationality basis of authority will also undergo change. Whether the authority power can be used as impetus to promote the development of modernization and the effect exhibited by authority are determined by whether we can or to what extent we can adopt appropriate authority forms. The necessary passage shall be from old authority to new authority and from totalitarian authority to democratic authority, which is the so-called elite democracy. Michael G. Roskin presents us with the relationship among authoritarianism, totalitarianism and elite democracy in Political Science. The transition cannot be accomplished in one action; it is a rather long reform, development and innovation process as well as a process where the public learn and accommodate themselves. 
The urgent affair now is to systematically transform into modern democracy with Chinese characteristics under the premise of a stable government authority. The authority of central government shall be optimized and at the same time, collectivity authority and enlightened authority rather than individual authority shall be stressed. The most effective way is to enhance the leadership of CPC to prevent from backing to individual authority under totalitarianism. The validity and power source of a Party's leadership is like as Huntington has pointed out "the stability of a political system in the process of modernization is determined by the power of its party, while the power of the party is determined by the public's supports for its systemization, so the power reflects the scale of supports and the systemization extent. Those countries who have actually reached or are considered to have reached high political stability and are in modernization at lease have one powerful party...... also, the probability of the emergence of violence, turbulence and other forms of political turbulence is a lot higher in political system without powerful party.

Table 1. The relationship between elite change and democratic consolidation of 13 countries in Latin America and southern Europe

\begin{tabular}{|l|l|l|}
\hline Country & Status of Elite Change & Types of Regime \\
\hline Argentina & Does not & Democracy not consolidated \\
\hline Brazil & Does no & Democracy not consolidated \\
\hline Colombia & May compromise(1989-90) & Democracy, may be consolidated \\
\hline Costa Rica & $\begin{array}{l}\text { Compromising/tend to } \\
\text { compromise (1948-70) }\end{array}$ & Consolidated democracy \\
\hline Dominica & $\begin{array}{l}\text { Gradually tend to consent } \\
\text { /compromise(1966-78) }\end{array}$ & Consolidated democracy \\
\hline Italy & $\begin{array}{l}\text { Gradually tent to } \\
\text { consent(1963-78) }\end{array}$ & Consolidated democracy \\
\hline Mexico & Compromised (1929) & $\begin{array}{l}\text { Stable and limited democracy or comprehensive } \\
\text { authoritarianism regime }\end{array}$ \\
\hline Peru & Dose not & Democracy not consolidated \\
\hline Portugal & $\begin{array}{l}\text { Gradually tent to consent } \\
\text { (1983-9) }\end{array}$ & Consolidated democracy \\
\hline Spain & Compromised (1977-9) & Consolidated democracy \\
\hline Uruguay & $\begin{array}{l}\text { Compromising/gradually } \\
\text { tend to (1984-90) }\end{array}$ & Consolidated democracy \\
\hline Venezuela & Compromised (1958) & Consolidated democracy \\
\hline
\end{tabular}

Table 2. The pedigree of government authority

\begin{tabular}{|l|l|l|l|l|l|}
\hline \multicolumn{2}{|c|}{ Democratic Government } & \multicolumn{2}{c|}{ Non-democratic Government } \\
\hline $\begin{array}{l}\text { Absolute } \\
\text { Democracy }\end{array}$ & Democracy & $\begin{array}{l}\text { Limited } \\
\text { Democracy }\end{array}$ & Authoritarianism & Totalitarianism & $\begin{array}{l}\text { Absolute } \\
\text { Totalitarianism }\end{array}$ \\
\hline No party & $\begin{array}{l}\text { Two parties } \\
\text { or } \\
\text { multi-parties }\end{array}$ & $\begin{array}{l}\text { One party } \\
\text { only }\end{array}$ & $\begin{array}{l}\text { One party or no } \\
\text { party }\end{array}$ & One party system & One party system \\
\hline
\end{tabular}

\subsection{From elite democracy to people's democracy}

Enlightened authority government can effectively harmonize stable social order and conflicts brought by the transformation of economy and society and is used to understanding, tolerating and respecting different opinions, a political culture that we must be seasoned with in the process of our marching towards democratization. We need an enlightened authority government to protect the immense achievement that we have gained in the reform and opening up through gradual change and advancement.

To judge from the development course of the democratization of China, in reality the mode that can effect functions is where the State dominates. Places where democratic election is carried out comparatively better are always under the local leaders' 
supports, that is the powerful supports of administration elites. They can smartly use democratic procedures. This is the road for elite democratization. We can borrow useful thought resources from western elitism theories and use them to promote the democratization course of China. In the democratization course of China, elitism, as a kind of ethos, can provide us with a comparatively practical and feasible road.

\section{References}

Dahl, Robert A. (1982). Dilemmas of pluralist democracy: autonomy vs. control. New Haven: Yale University Press.

Etzioni-Halevy, Eva. (1997). Classes and elites in democracy and democratization: a collection of readings. New York: Garland

Lasswell, Harold D., Lerner, Daniel \& Rothwell, C. Easton. (1952). The comparative study of elites; an introduction and bibliography. Stanford: Stanford University Press.

Palma, Giuseppe Di. (1990). To craft democracies: an essay on democratic transitions. Berkeley: University of California Press.

Putnam, Robert D. \& Cliffs, Englewood. (1976). The comparative study of political elites. N.J.: Prentice-Hall. 